\title{
PENGENALAN TULISAN TANGAN KARAKTER HIRAGANA MENGGUNAKAN DCT, DWT, DAN K-NEAREST NEIGHBOR
}

\section{RECOGNIZING HANDWRITTEN HIRAGANA CHARACTERS USING DCT, DWT, AND K-NEAREST NEIGHBOR}

\author{
Suci Aulia ST.,MT ${ }^{1}$, Arif Setiawan ST ${ }^{2}$ \\ Prodi D3 Teknik Telekomunikasi, Fakultas Ilmu Terapan \\ Universitas Telkom \\ ${ }^{1}$ sucia@ tass.telkomuniversity.ac.id, ${ }^{2} \underline{\text { ariffsetiawan52@gmail.com }}$
}

\begin{abstract}
Abstrak
Penelitian untuk mengenali karakter huruf hiragana berbasis image processing telah banyak dilakukan dan bahkan tingkat akurasi hampir mendekati $100 \%$. Namun citra masukkan yang digunakan masih berupa karakter huruf jepang hasil print-out sedangkan untuk masukkan berupa tulisan tangan belum dilakukan. Maka pada penelitian ini diujikan pengenalan huruf hiragana yang berasal dari tulisan tangan berformat .jpeg. Dari beberapa strudi terkait, pendekatan kompresi yang paling sering digunakan untuk citra JPEG adalah algoritma DCT dan DWT, sehingga kedua algoritma tersebut digunakan pada penelitian ini untuk diujikan dan dibandingkan performansinya. Pada sistem diujikan 45 citra dari 3 orang tulisan tangan karakter hiragana dengan klasifikasi berbasis KNN dimana sebelumnya 45 citra yang berbeda dari 3 orang tersebut di training oleh masing-masing algoritma DWT dan DCT. Hasilnya berdasarkan parameter jarak yang ada pada algoritma KNN, algoritma DWT lebih unggul dibandingkan algoritma DCT. Pencapaian tingkat akurasi maksimum diperoleh untuk masing-masing algoritma DWT-DCT adalah pada parameter cityblok $82.61 \%$ (DWT) dan correlation $58.70 \%$ (DCT).
\end{abstract}

\section{Kata kunci : Hiragana, DWT, DCT, KNN}

\begin{abstract}
Research to recognize hiragana character based image processing has been widely practiced and even the accuracy level is close to $100 \%$. However, the input image that used is still in the form of japanese characters print-out while the handwriting has not been studied. So in this study tested the recognition of hiragana letters derived from handwriting format. Jpeg. Of the several related studies, the most commonly used compression approach for JPEG images is the DCT and DWT algorithms, so both algorithms are used in this study to be tested and compared their performance. In the system tested 45 images of 3 people handwriting hiragana character with KNN-based classification where previously 45 different images of the 3 people are trained by each DWT and DCT algorithms. The result is based on the distance parameters that exist in the KNN algorithm, the DWT algorithm is superior to the DCT algorithm. The achievement of the maximum accuracy level obtained for each DWT-DCT algorithm is on the cityblock distance parameter $82.61 \%$ (DWT) and correlation distance $58.70 \%$ (DCT).
\end{abstract}

Keywords: Hiragana, DWT, DCT, KNN

\section{PENDAHULUAN}

Tulisan bahasa Jepang terdiri dari tiga jenis yaitu kanji logografi (karakter Tionghoa), syllabic Kana. Kana adalah sistem syllabic, di mana satu pengucapan selalu diwakili oleh sepasang karakter yaitu, hiragana dan katakana. Sebaliknya, sebagian besar karakter kanji yang digunakan dalam bahasa Jepang sehari-hari memiliki dua atau lebih pengucapan yang berbeda[1]. Karena ada jenis karakter hiragana dan katakana pada setiap pengucapan sehingga terdapat tantangan dalam 
mengenali setiap jenis sistem tulisannya. Selain itu, gaya penulisan dari masing-masing jenis tulisan bisa sangat bervariasi untuk setiap orang. Perbedaannya lebih terasa untuk tulisan hiragana karena bersifat lebih kursif.

Penelitian yang berhubungan dengan pengenalan huruf hiragana diantaranya mendapatkan tingkat akurasi mencapai $80 \%$ dengan konsep passive finger tracing[1], $\approx 100 \%$ dengan optimasi penggabungan algoritma Fuzzy dan SVM [2][3], 94.1\% dengan STRICR-FB [4], $83.33 \%$ dengan algoritma JST SOM[5].

Pada penelitian ini,tulisan karakter hiragana menjadi masukkan sistem. Masukkan sistem berasal dari tulisan tangan pada kertas putih sebagai background-nya kemudian difoto dan disimpan dalam format .jpeg. Tehnik kompresi yang sering direkomendasikan untuk .jpeg adalah pendekatan menggunakan Discrete Cosine Transform (DCT) dari 8'8 sub-blok4 [6][7][8]. Selain itu, sebuah kelas transformasi baru disebut Discrete Wavelet Transform (DWT) memberikan hasil yang lebih baik dalam aspek ruang (domain spatial) dan juga eksekusi waktu. Pendekatan kompresi terhadap JPEG dengan menggunakan wavelet telah banyak dilakukan untuk menghemat waktu komputasi [9][8][10] . Oleh karena itu, pada penelitian ini dibandingan performansi dari algoritma DWT dan DCT untuk mengenali karakter hiragana yang berasal dari tulisan tangan. Untuk proses klasifikasi, digunakan algoritma KNN dengan konsep pemilihan jarak terdekat [11][12].

\section{DASAR TEORI}

\subsection{KNN(K-Nearest Neighbor)}

KNN mengklasifikasikan suatu sampel data (perbaris pada matriks) ke dalam suatu grup berdasarkan pengelompokkan data hasil training. Data sampel dan data uji harus berupa matriks dengan ukuran yang sama. Setiap data dilihat nilainya oleh KNN kemudian diklasifikasikan ke grup pada kolom pengujian berdasarkan jarak terdekat. Grup dapat berupa vektor numerik, vektor karakter, atau rangkaian sel dari vektor karakter. Beberapa metoda untuk menghitung jarak terdekat pada KNN diantaranya Euclidean, cityblock, cosine, correlation, dan hamming .

Selain beberapa metoda pencarian jarak terdekat, pada algoritma KNN terdapat juga beberapa rule yang dipilih untuk membuat suatu keputusan dalam mengklasifikasikan sejumlah data sampel. Pilihan rule tersebut adalah nearest rule, random rule, consensus dan rule.

\subsection{DWT (Discrete Wavelet Transform)}

DWT merupakan suatu urutan sejumlah koefisien diskrit yang merupakan hasil pemetaan dari variabel kontinyu pada deret wavelet .

Seperti contoh $f_{n}=f\left(x_{0}+n \Delta x\right), n=0,1,2, \ldots, M-1$. Maka berikut merupakan persamaan untuk mencari nilai koefisien DWT [13][14]:

$$
\begin{aligned}
& W_{\varphi}\left(j_{0}, k\right)=\frac{1}{\sqrt{M}} \sum_{n} f_{n} \varphi_{j_{0}, k}(n) \\
& W_{\varphi}(j, k)=\frac{1}{\sqrt{M}} \sum_{n} f_{n} \Psi_{j, k}(n), \text { untuk } j \geq j_{0}
\end{aligned}
$$

\subsection{DCT (Discrete Contious Transform)}

Algoritma DCT seringkali dipakai dalam berbagai aplikasi, salah satunya adalah untuk kompresi data citra. Sebagai contohnya, gambar.1 menunjukkan perbedaan suatu citra asli dengan citra yang telah dikompesi dengan algoritma DCT. Sesuai dengan namanya, DCT bertugas menstransformasikan suatu citra dari domain spasial ke domain frekuensi. Setelah data diubah ke domain frekuensi, langkah selanjutnya adalah memisahkan data berfrekuensi rendah dengan data yang berfrekuensi tinggi. Kemudian DCT hanya akan memilih data berfrekuensi rendah, hal ini disebabkan karena secara visual lebih dominan dibandingan dengan data berfrekuensi tinggi. 
Sehingga citra yang telah melalui proses teknik kompresi DCT secara ukuran akan lebih kecil namun tidak ada perubahan yang terlalu signifikan secara visual.

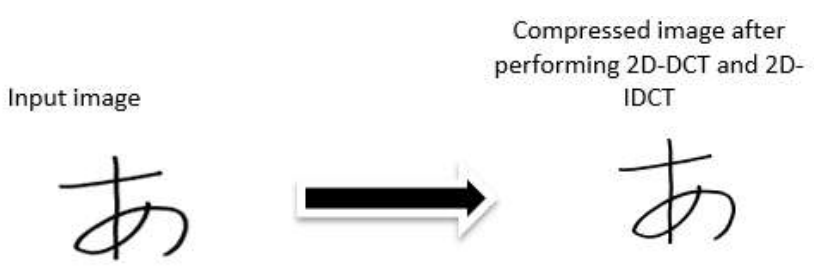

Gambar. 1 Proses kompresi citra dengan algoritma DCT.[6]

Berikut merupakan persamaan algoritma DCT-2D [6]untuk suatu matriks $\mathrm{S}$ berukuran $\mathrm{MxN}$ :

$$
B_{p q}=\alpha_{p} \alpha_{q} \sum_{m=0}^{M-1} \quad \sum_{m=0}^{M-1} \quad A_{m n} \cos \left(\frac{\pi(2 m+1) p}{2 M}\right) \cos \left(\frac{\pi(2 n+1) p}{2 n}\right)
$$

Pers (1) di atas berlaku pada kondisi $(0 \leq p \leq M-1)$ dan $(0 \leq q \leq N-1)$ dimana :

$$
\alpha_{p}=\left\{\begin{array}{l}
\sqrt{\frac{1}{M}}, p=0 \\
\sqrt{\frac{2}{M}}, 0 \leq p \leq M-1
\end{array} \quad \alpha_{q}=\left\{\begin{array}{l}
\sqrt{\frac{1}{N}}, q=0 \\
\sqrt{\frac{2}{N}}, 0 \leq q \leq N-1
\end{array}\right.\right.
$$

\section{METODOLOGI PENELITIAN}

Secara umum, metodologi pada penelitian ini terdiri dari beberapa tahap yaitu :

1. Akuisi citra : pada proses ini dilakukan pengambilan citra dimana pada prosesnya berpengaruh pada jarak, jenis kamera, dan pencahayaan. Setelah diujikan posisi terbaik, maka data-data tersebut dikelompokkan untuk kemudian dijadikan sebagai data latih dan data uji. Gambar.2a menujukkan citra hasil akuisi dari tulisan tangan pada kertas HVS.

2. Preprocessing : merupakan proses sebelum dilakukan pengambilan ciri oleh algoritma DWT maupun DCT. Pada preprocessing ini operasi morfologi dasar yang digunakan seperti grasyscaling, binering image, cropping, erosi, dan dilation. Gambar.2b menunjukkan hasil akhir dari preprosesing.

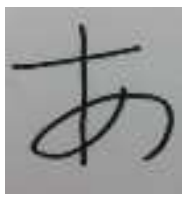

(a)

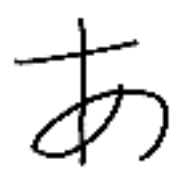

(b)

Gambar. 2.(a) Citra masukkan asli. (b) Citra masukkan setelah preprocessing.

3. Ekstraksi Ciri DCT : pada proses ini, citra biner dikompresi oleh algoritma DCT. Koefisien hasil kompresi tersebut merupakan koefisien ciri dari citra masukkan. Gambar.3a,b menunjukkan perbedaan informasi pada citra sebelum dan setelah kompresi oleh DCT.

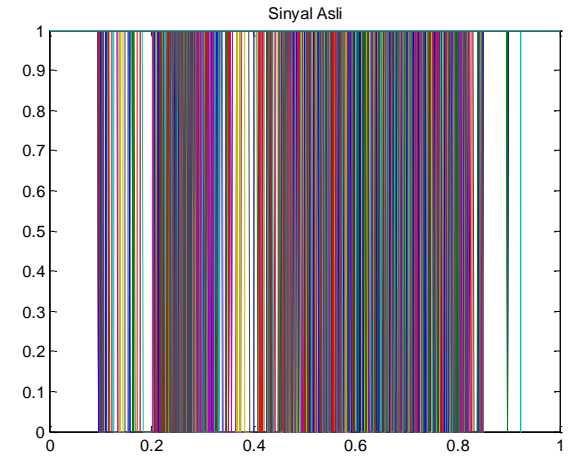

(a)

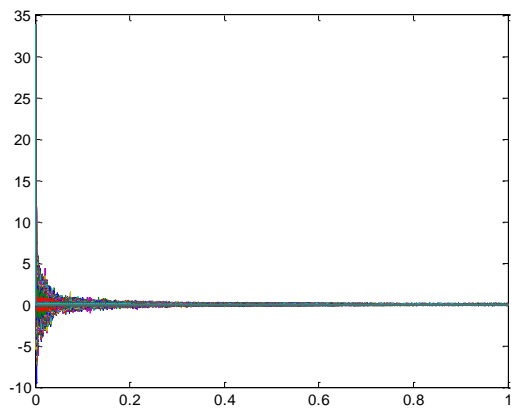

(b)

Gambar. 3 .(a) Informasi Citra masukkan asli. (b) Informasi Citra masukkan setelah proses DCT. 


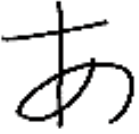

(a)

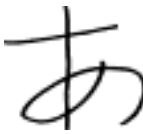

(b)

Gambar. 4. (a) Citra sebelum DCT. (b) Citra hasil invers DCT (IDCT)

Gambar.4 merupakan citra yang dikembalikan setelah melalui proses DCT atau sering disebut invers-DCT (IDCT). Dari segi ukuran, citra sebelum proses DCT dan citra setelah proses IDCT adalah sama yaitu 864x994. Apabila dilihat dari Gambar.3a dan 3b perbandingan informasi yang ada sangat jauh berbeda, namun secara kasat mata dari gambar.4a,b tidak terlihat perbedaan yang signifikan selain tulisan menjadi lebih tipis.

4. Ekstraksi Ciri DWT : pada proses ini, citra biner dikompresi oleh algoritma DWT. Koefisien hasil kompresi tersebut merupakan koefisien ciri dari citra masukkan.

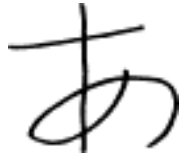

LL

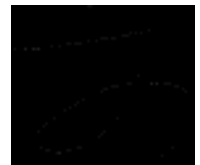

$\mathrm{LH}$

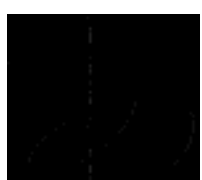

HL

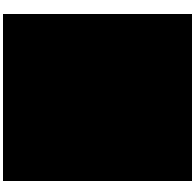

$\mathrm{HH}$

Gambar. 5. Informasi pada setiap citra LL,LH,HL dan HH pada komposisi DWT.

Gambar.5 merupakan pembuktian dari algoritma DWT. DWT membagi citra menjadi 4 bagian berdasarkan frekuensi yaitu blok Low-Low (LL), blok Low-High (LH), blok High-Low (HL),dan blok High - High (HH). Informasi merupakan citra dengan frekuensi rendah (Low-Low) seperti yang ditunjukkan pada Gambar.5. Gambar.6 menunjukkan informasi yang ada pada setiap blok komposisi DWT dalam domain kontinyu, dimana CA1 merupakan citra LL, CH1 merupakan citra LH, CV1 merupakan citra HL dan CV1 merupakan citra HH. Ukuran dari masing-masing blok komposisi adalah $432 \times 497$ piksel, lebih kecil $\approx 50 \%$ dari citra asli sehingga efisien apabila digunakan untuk proses kompresi.

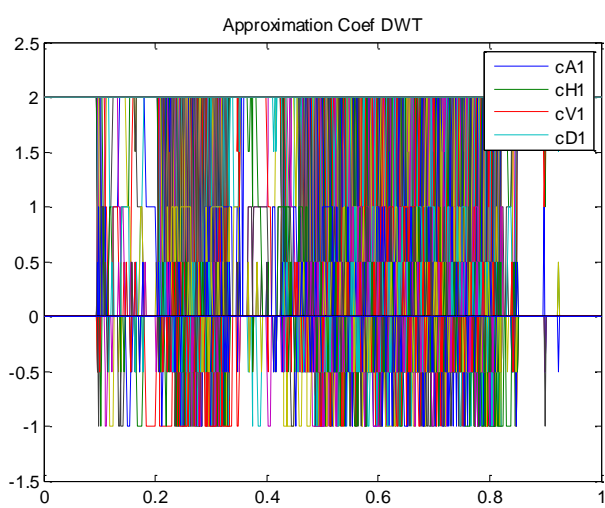

Gambar. 6. Hasil dekomposisi single level- DWT domain kontinyu.

5. Klasifikasi : proses ini adalah pengujian dengan citra yang berbeda dari citra masukkan untuk pengambilan ekstraksi ciri. Semua citra uji di klasifikasikan dengan algoritma KNN. Hasilnya kemudian dianalisa untuk mendapatkan algoritma terbaik diantara DWT-DCT. 


\section{HASIL DAN ANALISIS}

Pada bagian ini akan menjabarkan hasil pengujian terhadap beberapa parameter untuk mengetahui tingkat akurasi sistem, diantaranya parameter jarak dan rule.

\subsection{Pengujian Parameter Jarak}

Pada pengujian sistem, setiap data uji diambil 30 sample yang mewakili berbagai huruf hiragana. Pada pengujian ini, terdiri dari 3 jenis data uji sehingga total menjadi 90 sample .Setiap sample data diujikan berdasarkan jarak KNN yaitu Euclidean, Cityblock, Cosine, dan Correlation dengan menggunakan algoritma DWT dan DCT untuk proses ekstraksi ciri. Berikut grafik tingkat akurasi berdasarkan parameter jarak dengan algoritma DWT dan DCT diperlihatkan pada gambar 7 dan gambar 8.

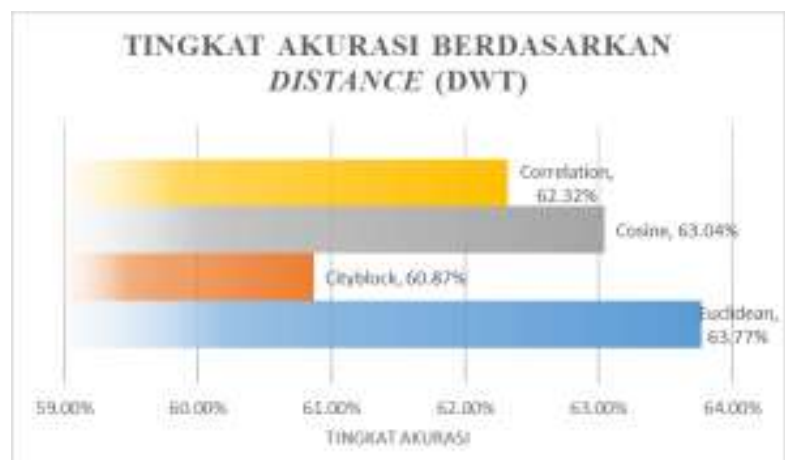

Gambar. 7 Grafik tingkat akurasi sistem berdasarkan parameter jarak KNN dengan algoritma ekstraksi ciri DWT.

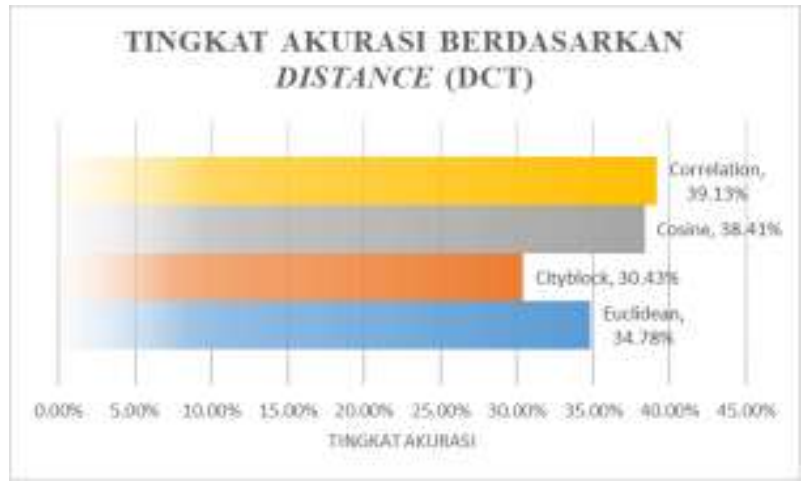

Gambar. 8 Grafik tingkat akurasi sistem berdasarkan parameter jarak KNN dengan algoritma ekstraksi ciri DCT.

Berdasarkan grafik pada gambar.7, tingkat akurasi maksimum diperoleh $62.32 \%$ untuk ekstraksi ciri dengan algoritma DWT (Euclidean distance) dan $39.13 \%$ untuk ekstraksi ciri dengan algoritma DCT (Correlation distance). Sehingga yang menjadi catatan dari hasil pengujian ini adalah algoritma ekstraksi ciri DWT lebih unggul daripada algoritma DCT dengan rata-rata tingkat akurasi masing-masing adalah $62.50 \%$ dan $35.99 \%$. 


\subsection{Pengujian Parameter Setiap Jarak Terhadap Rule}

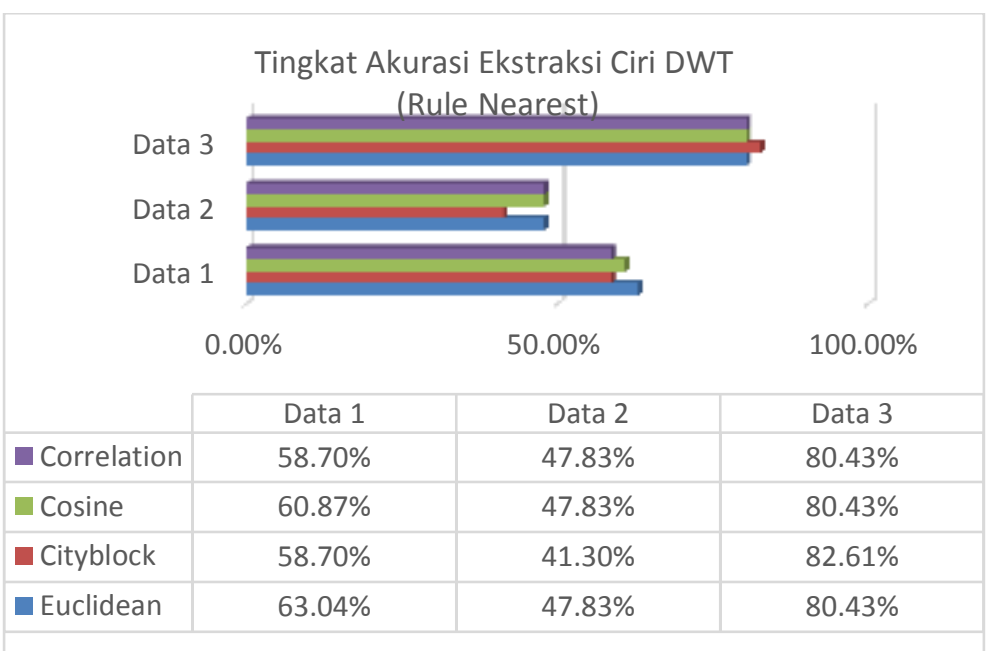

(a)

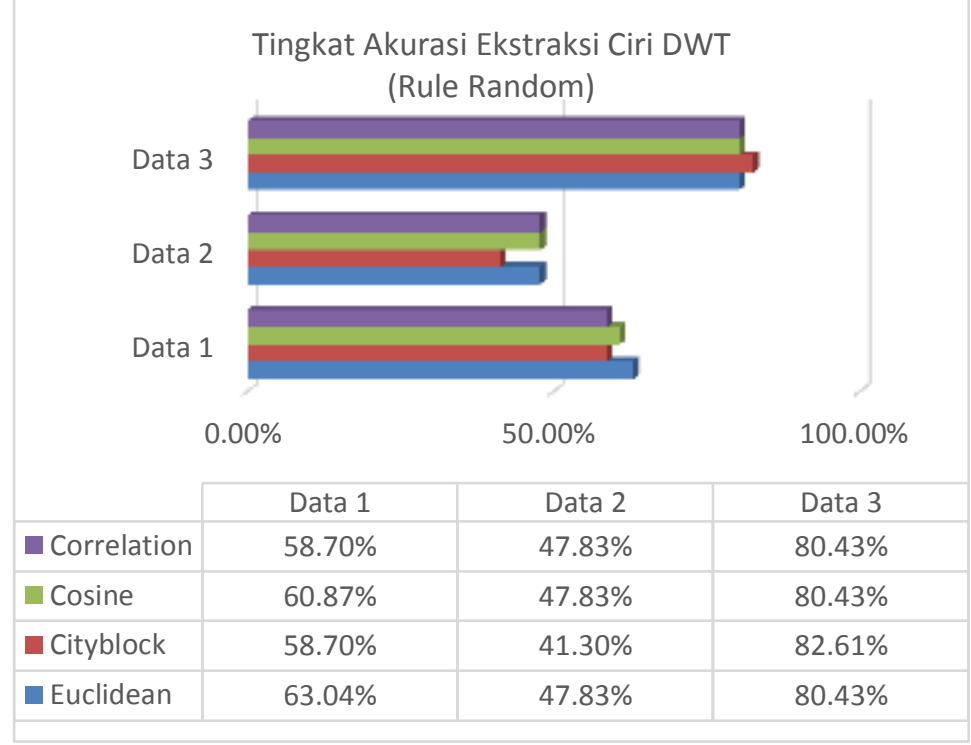

(b)

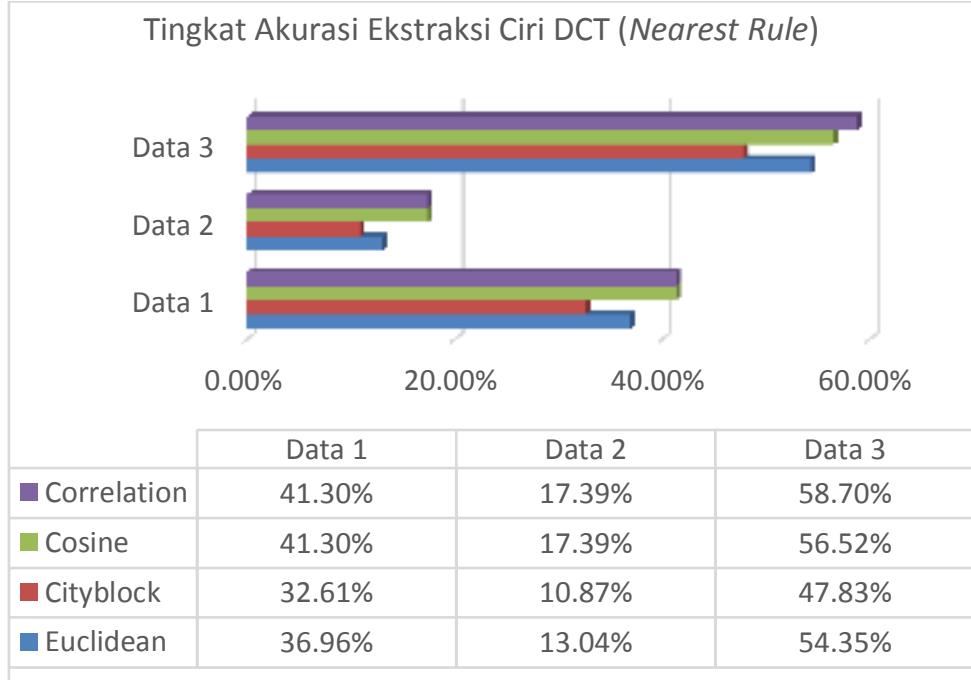

(c)

Gambar. 9 Grafik pengaruh tingkat akurasi sistem berdasarkan parameter jarak KNN terhadap rule KNN .(a) Nearest Rule (DWT), (b) Random Rule (DWT), (c) Nearest Rule (DCT). 
Berdasarkan Gambar 9a dan 9b, parameter jarak KNN tidak berpengaruh terhadap parameter rule KNN yaitu setiap jarak (Euclidean, Cityblock, Cosine, dan Correlation) terhadap setiap rule (Nearest,Random, Consensus). Sama halnya seperti pada pengujian dengan menggunakan ekstraksi ciri DWT, pada pengujian dengan menggunakan ekstraksi ciri DCT parameter rule KNN tidak memberikan pengaruh seperti yang terlihat pada Gambar 9c.

\subsection{Pengujian Tingkat Akurasi Data Uji}

Pada pengujian ini, dilakukan pengujian rata-rata tingkat akurasi untuk setiap data uji .Data 1, Data 2, dan Data 3 merupakan data berupa hasil capture tulisan tangan huruf hiragana dari tiga orang yang berbeda. Setiap data diujikan terhadap empat parameter jarak untuk masing-masing algoritma ekstraksi ciri DWT dan DCT. Berikut hasilnya dapat dilihat pada Gambar 10.

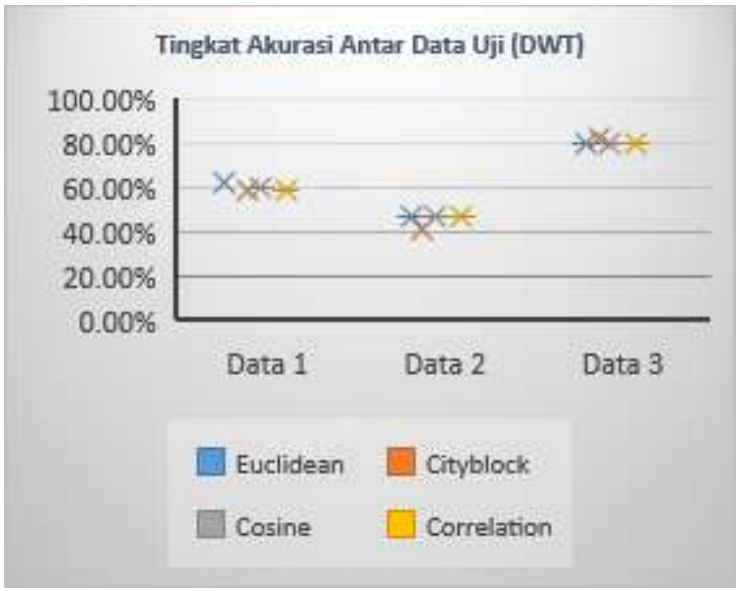

(a)

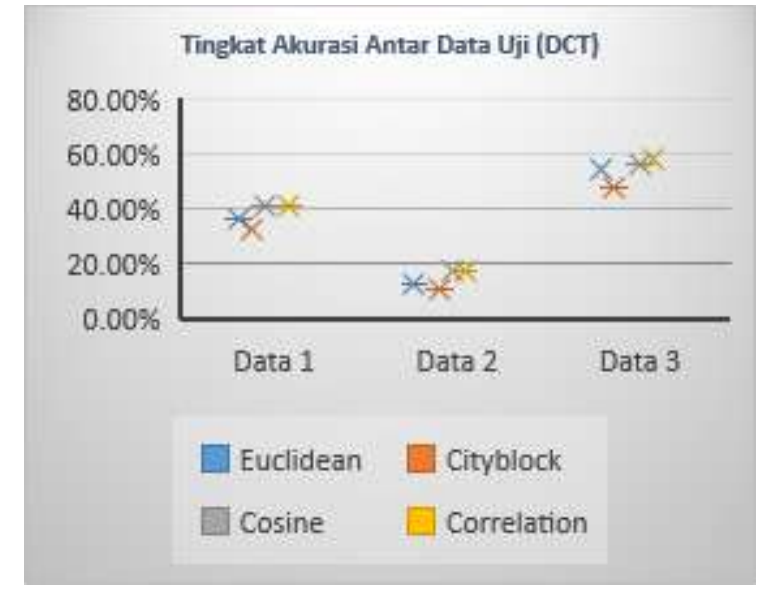

(b)

Gambar. 10 Grafik perbandingan tingkat akurasi antar data uji berdasarkan parameter jarak KNN. (a). Ekstraksi ciri DWT, (b) Ekstraksi ciri DCT.

Dari gambar 10a dan 10b di atas dapat dilihat bahwa Data 3 konsisten mencapai nilai akurasi tertinggi dibandingkan Data 1 dan Data 2 baik dengan menggunakan algoritma ekstraksi ciri DWT maupun DCT saat diujikan terhadap empat parameter jarak KNN. Pada pengujian dengan ekstraksi ciri DWT (gambar 10a), tingkat akurasi Data 3 untuk masing-masing jarak (Euclidean, Cityblock, Cosine, dan Correlation) adalah 80.43 \%, 82,61 \%, 80,43\% dan 80, $43 \%$. Nilai maksimum diperoleh pada saat pengujian dengan parameter jarak Cityblock.

Sedangkan pada pengujian dengan ekstraksi ciri DCT (gambar 10b), tingkat akurasi Data 3 untuk masing-masing jarak (Euclidean, Cityblock, Cosine, dan Correlation) adalah 54.35 \%, 47,83\%, $56.52 \%$ dan $58,70 \%$. Nilai maksimum diperoleh pada saat pengujian dengan parameter jarak Correlation. Dari gambar 10a,b dapat ditarik kesimpulan bahwa algoritma ekstraksi ciri DWT lebih unggul dibandingakan DCT berdasarkan nilai rata-rata akurasi Data 3 masing-masing adalah $80.98 \%$ dan $54.35 \%$.

\subsection{Pengujian Tingkat Akurasi Maksimum}

Berdasarkan pengujian sebelumnya, diperoleh bahwa Data 3 merupakan data yang memiliki tingkat akurasi tertinggi dibandingkan data lainnya yaitu Data 1 dan Data 2. Maka pada bagian ini, dilakukan pengujian pengaruh parameter rule KNN terhadap tingkat akurasi yang dilakukan hanya berdasarkan sample dari Data 3 saja. Hasilnya dapat dilihat pada gambar.11 untuk algoritma ekstraksi ciri DWT dan gambar.11 untuk algoritma ekstraksi ciri DCT. 


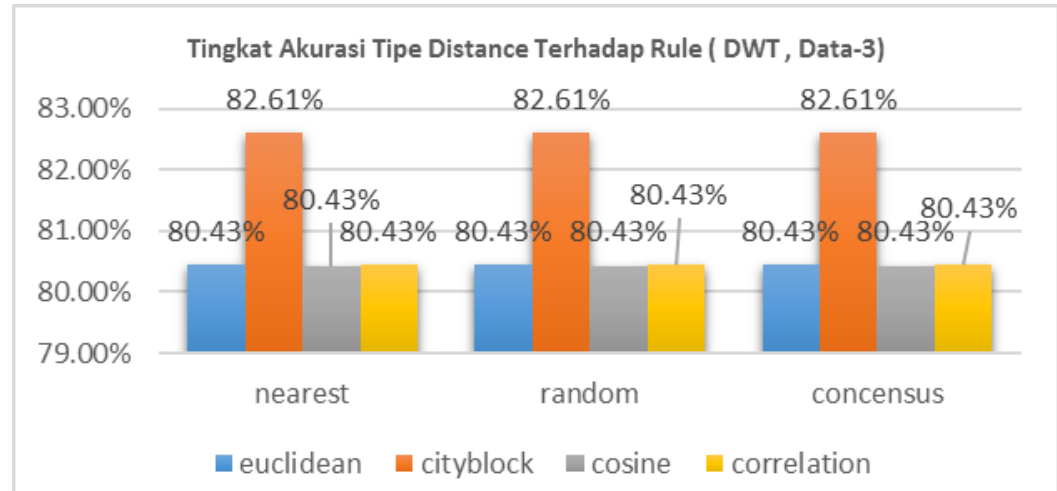

Gambar. 11 Grafik pengaruh rule KNN terhadap tingkat akurasi pada Data-3 dengan algoritma ekstraksi ciri DWT.

Sama halnya seperti pengujian yang terlihat pada gambar.9a,b,c, dan pada gambar.11 , gambar.12 memperlihatkan bahwa pada Data 3 parameter rule tidak berpengaruh terhadap tingkat akurasi. Dibuktikan dengan tingkat akurasi maksimum diperoleh $82.64 \%$ pada cityblock jarak (DWT) dan $58.70 \%$ pada correlation jarak (DCT) untuk masing-masing rule (nearest, random, consensus).

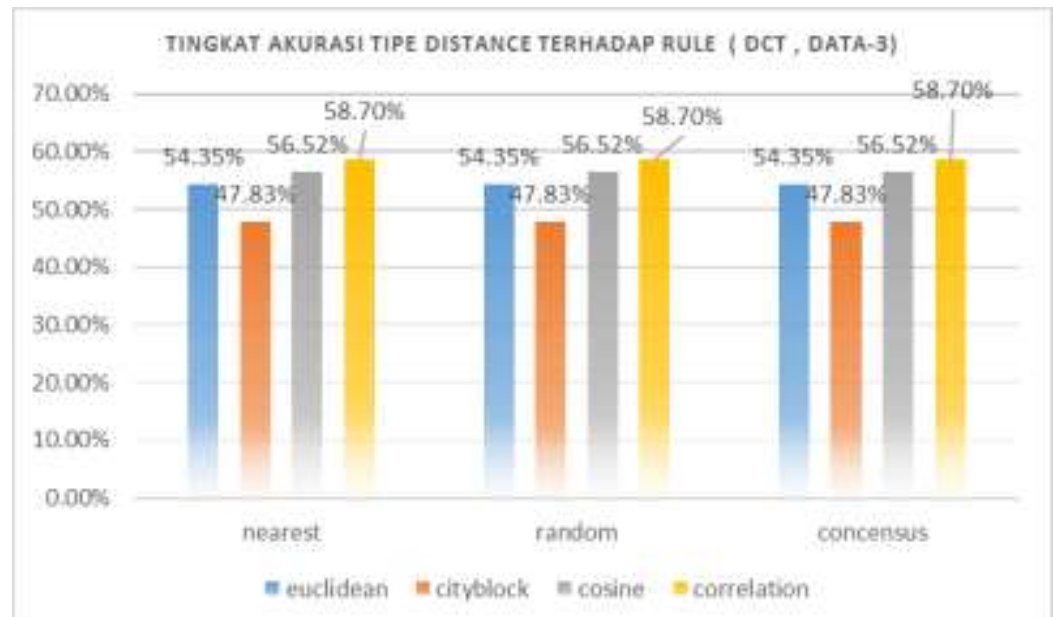

Gambar. 12 Grafik pengaruh rule KNN terhadap tingkat akurasi pada Data-3 dengan algoritma ekstraksi ciri DCT.

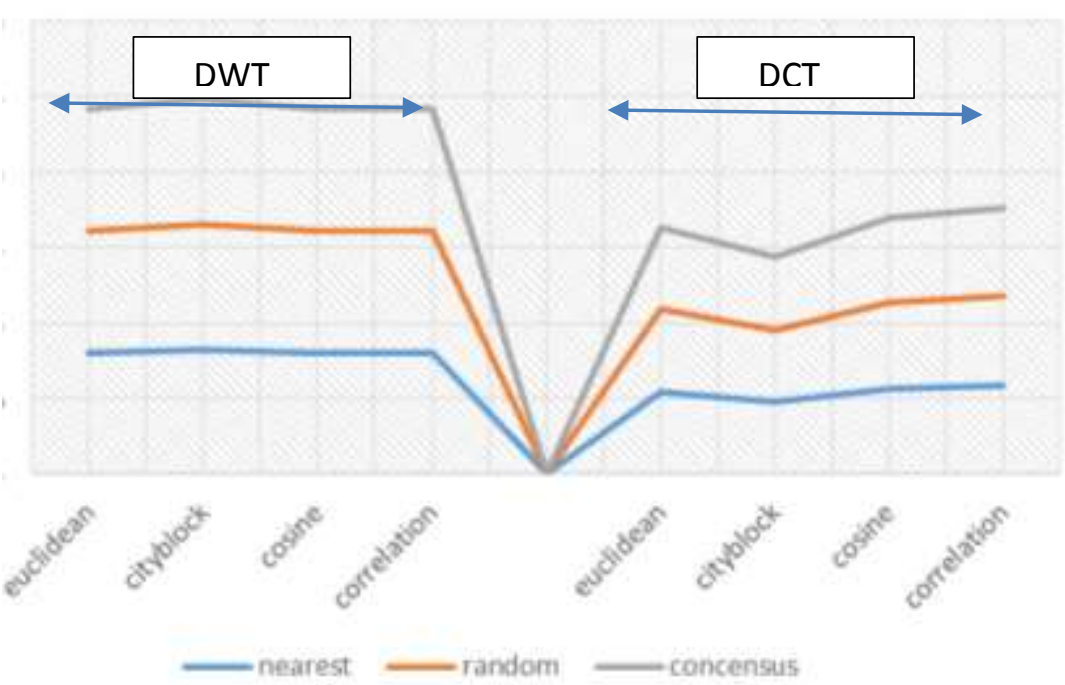

Gambar. 13 Grafik perbandingan tingkat akurasi algoritma ekstraksi ciri DWT dengan DCT. 
Dari gambar 13 di atas dapat dilihat bahwa rata-rata tingkat akurasi Data 3 untuk setiap jenis jarak dan rule sebagai parameter dari KNN, algoritma ekstraksi ciri DWT lebih unggul dari pada DCT yaitu masing-masing $80.98 \%$ dan $54.35 \%$. Berikut adalah perbandingan tingkat akurasi setiap parameter jarak KNN (DWT-DCT) : Euclidean 80.43\%-54.35\%, Cityblock 82.61\%-47.83\%, Cosine 80.43\%-56.52\% , dan Correlation 80.43\%-58.70\%.

\section{Kesimpulan}

Pada penelitian ini, diujikan algoritma KNN untuk mendeteksi huruf hiragana dengan menggunakan dua algoritma ekstraksi ciri yaitu Discrete Wavelet Transform (DWT) dan Discrete Cosine Transform (DCT) sebagai perbandingan. Adapun data yang digunakan adalah berupa captured image dari tulisan tangan huruf hiragana dengan background tulisan tanpa noise yaitu bewarna putih. Dari hasil pengujian berdasarkan parameter jarak dan rule yang ada pada algoritma KNN, algoritma ekstraksi ciri DWT pada sistem ini lebih unggul dibandingan algoritma ekstraksi ciri DCT.

Setelah mengujikan tingkat akurasi dalam mendeteksi dan mengklasifikasi huruf hiragana antar data uji, data uji yang memiliki tingkat akurasi maksimum selanjutnya menjadi input untuk setiap pengujian perbandingan algoritma DWT dan DCT. Data 3 merupakan data dengan hasil uji tingkat akurasi tertinggi diantara data uji lainnya, dari hasil pengujian diperoleh bahwa algoritma DWT lebih unggul dari algoritma DCT. Adapun tingkat akurasi rata-rata Data 3 yang diperoleh untuk masing-masing algoritma DWT dan DCT adalah $80.98 \%$ dan $54.35 \%$. Sedangkan tingkat akurasi maksimum Data 3 diperoleh pada parameter cityblok jarak $82.61 \%$ (DWT) dan correlation jarak $58.70 \%$ (DCT). Jika dibandingkan dengan metoda sebelumnya, tingkat akurasi dari metoda DWT-KNN maupun DCT-KNN masih lebih rendah hal ini dikarenakan untuk masukkan yang digunakan berasal dari tulisan tangan. Sedangkan pada penelitian sebelumnya yang telah disebutkan pada bagian pendahuluan menggunakan karakter Jepang hasil print-out atau cetak.

\section{Daftar Pustaka:}

[1] H. Yamashita.2014. Recognition of Japanese Phonographic Kana ( Hiragana) and Logographic Kanji Characters by Passive Finger Tracing. no. March, pp. 213-219.

[2] M. Doumpos, C. Zopounidis, dan V. Golfinopoulou.2007. Additive support vector machines for pattern classification. IEEE Trans. Syst. Man. Cybern. B. Cybern., vol. 37, no. 3, pp. 540-50, 2007.

[3] N. Tsuchiya, S. Ozawa, dan S. Abe.2000. Training three-layer neural network classifiers by solving inequalities. Proc. Int. Jt. Conf. Neural Networks, vol. 3, no. 1.

[4] S. Das dan S. Banerjee. 2014. An Algorithm for Japanese Character Recognition. Int. J. Image, Graph. Signal Process., vol. 7, no. 1, pp. 9-15.

[5] W. Fitria, K. Usman, dan D. Mursita.2010. Desain dan Implementasi Sistem Penerjemah Huruf Jepang Kana (Hiragana-Katakana) Ke Huruf Latin Berbasis Pengolahan Citra Digital Dan Jaringan Syaraf Tiruan Self-Organizing Map (SOM) Menggunakan Webcam. pp. 9.

[6] F. N. Jawad Nagi dan Syed Khaleel Ahmed.2008. A MATLAB based Face Recognition System using Image Processing and Neural Networks. 4th Int. Colloqium Signal Process. its Appl., pp. 83-88.

[7] S.S. Tamboli dan V.R.Udupi.2013. Optimum DCT Image Compression using Neural Networks Arbitration. Int. J. Electron. Commun. Instrum. Eng. Res. Dev., vol. 3, no. 1, pp. 9-14.

[8] C. Science dan S. Engineering.2014. Image Compression Technique under JPEG by Wavelets Transformation. Int. J. Adv. Res. Comput. Sci. Softw. Eng., vol. 4, no. 6, pp. 808818.

[9] J. Frank, S. Mannor, J. Pineau, dan D. Precup.2012. Time Series Analysis Using Geometric 
Template Matching. IEEE Trans. Pattern Anal. Mach. Intell., vol. 35, no. 3, p. 1.

[10] K. M. Rajpoot dan N. M. Rajpoot.2004. Wavelets and support vector machines for texture classification. in Multitopic Conference, 2004. Proceedings of INMIC 2004. 8th International, pp. 328-333.

[11] S. Aulia, S. Hadiyoso, dan D. N. Ramadan. 2015. Analisis Perbandingan KNN dengan SVM untuk Klasifikasi Penyakit Diabetes Retinopati berdasarkan Citra Eksudat dan Mikroaneurisma. J. ELKOMIKA -Teknik Elektro Itenas - ISSN 2338-8323, vol. 3, no. 1, pp. 75-90.

[12] I. V. Yuliani dan S. Aulia.2016. The supporting system for assessment of catwalk modeling using variable module graph method based on video. in 2016 4th International Conference on Information and Communication Technology, ICoICT 2016, pp. 1-5.

[13] R. Gonzalez dan R. Woods.2007. Digital Image Processing.

[14] R. C. . Gonzalez dan R. E. Woods.2008. Digital image processing. Nueva Jersey. p. 976. 